\title{
Who Are the Market Beaters: Lucky Investors, Insiders or Who Else?
}

\author{
Yusuf Varlı ${ }^{\mathrm{a}}$
}

\begin{abstract}
Conditions of beating the market is always top of the interests of investors throughout the history. In this study we aim to find who beats the market using a special trade and portfolio data from a stock exchange namely Borsa istanbul. Instead of market data, investor based data used in this paper provides us to make stronger analyses. We initially find that $87 \%$ of individual and $92 \%$ of institutional investors get returns in a random way. Then the rest of investors are investigated to determine who consistently beats the market and gets abnormal returns. And we mainly find that the market beating gets longer with increasing portfolio size and diversification, while it gets shorter with increasing turnover. Additionally, longer beating length means higher shares of women, old adults, funds and foreigner. Furthermore, we analyze the return performance of investors in our study and show that the picture becomes reversed compared to beating length criteria. Finally, the insiders are compared with other investors to understand whether the market is efficient in the strong form or not. And the findings indicate that the insiders cannot be specifically differentiated from other investors. Therefore, we end up with the evidence that there is strong form efficiency in Borsa istanbul.
\end{abstract}

Keywords: Market Beating, Abnormal Returns, Individual Investors, Institutional Investors, Insider Trading, Market Efficiency

JEL Classification: G10, G11, G12, G14

\section{Introduction}

Over-performance of investors is always one of the most interesting topics in Finance. There are academic and non-academic books, papers and newspaper columns which explain the secrets of the market, but we can see only some investors such as Warren Buffet, and George Soros who consistently beat the market. The question of whether markets are efficient is central to investment valuation. Those who do valuation well will be able to make 'higher' returns than other investors, because of their capacity to spot under and over-valued firms (Damodaran, 2012). That's why, having an idea about whether the market is efficient, or to what extent it is efficient is crucial in making investment decisions.

The recent financial crisis has also revealed the need of understanding the structure of financial markets. Analyses in both the academia and the industry have re-focused on the basics of definitions, descriptions and theories. One of the things which have come up for discussion in recent years is Efficient Market Hypothesis (Malkiel \& Fama, 1970). There are several studies (Basu, 1977; Fama, 1991) that are trying to question the relevance of the hypothesis. 
Most of the literature for the market efficiency emphasizes the role of informational efficiency. While Malkiel and Fama (1970) has an evidence of weak form and semi-strong form efficiencies, Fama (1991) states the stronger form of efficiency. In this study we are mainly interested with the strong form efficiency. Strong from of market efficiency implies that prices reflect all private (inside) information. This form of efficiency investigates whether investors can earn abnormal profits by trading on private information. Testing for strong form of efficiency focuses on the groups of insiders whether any private information can be used to generate abnormal returns (Chaudhuri, 1991; Del Brio, Miguel, \& Perote, 2002; Tahaoglu \& Guner, 2011).

There are some studies which define the efficiency by considering market beating situations. Fama (1995) which is one of the pioneer studies related to the relationship between market efficiency and beating the market, mainly indicates that there is no actual situation of consistently beating the market under the conditions of rationality in the market. According to Statman (2011), "The modest definition of efficient markets is their definition as unbeatable markets". In this study, the term of 'unbeatable market' is defined with the condition of the inability of investors to generate consistent positive alphas from their security investments. Coval, Hirshleifer and Shumway (2005) also employs the market beating conditions for the definition of market efficiency. Here, in accordance with this paper, risk adjusted return performance of investors should be random in line with the efficient market hypothesis unless there is a private information for investors.

On the other hand, the fact remains that some studies in the literature investigate how investors beat the market. The literature related to how or who beats the market generally focus on individual investors. For example, Coval et al. (2005) provides evidence that while some individual investors underperform the market, other investors have superior investment skills. By learning about and developing their ability through trading, investors can get abnormal returns. Barber and Odean (2000) states that the best-performing individual investors outperform the market on average by 0.5 percent per month. The most remarkable conclusion that they reach is that individual investors with high trading levels show poor performance. So they conclude that trading is hazardous to wealth of individual investors.

A current study of Dahlquist, Martinez and Söderlind (2016) finds that active investors earn significantly higher returns than inactive investors. In this study, performance decomposition analysis demonstrates that most of the outperformance of active investors results from these investors successfully timing their investments in funds and asset classes. Moreover, several studies document the similar conclusions due to the fact that individual investors appear to trade too much, have under-diversified portfolios, and hold onto underperformed positions for too long (Van Horne, Blume, \& Friend, 1975; Ferris, Haugen, \& Makhija, 1988; Odean, 1998; Odean, 1999; Grinblatt \& Keloharju, 2001).

Besides the general framework in the literature which is mainly depend on the analysis of trading activities and skills of individual investors, limited number of studies refer to demographic specifications of individual investors. For example; Bauer, Cosemans and Eichholtz (2007) reaches strong evidence of individual investors' persistent performance, which is only partly driven by persistence in trading costs. According to their findings, women are more likely to be consistent winners than men and investors who beat the market hold larger accounts with lower turnover. Barber and Odean (2001) reports that returns of individual investors are different in terms of their gender. In this study, it is found that men earn lower riskadjusted returns due to holding riskier portfolios. Additionally, Korniotis and Kumar (2011) reveals that older investors, though more knowledgeable about investment, have inferior stock selection ability.

On the other hand, some studies focus on the performance of institutional investors. Peikun and Yutao (2009) finds an evidence that Institutional investors' position change is positively correlated with abnormal return. They investigate whether institutional investors have information advantage and reveal that institutional investors are better informed compared to individual investors. Similarly, using a complete trading history data of all investors in Taiwan, Barber, Lee, Liu and Odean (2009) documents that institutional investors enjoy an annual performance boost of 1.5 percentage points and foreign institutions collect nearly half of institutional profits. Several other studies concentrate on the performance of funds especially mutual 
funds and show that mutual funds perform better than the market and get abnormal returns (Lehman \& Modest, 1987; Brown, Goetzmann, Ibbotson, \& Ross, 1992; Wermers, 1997).

Using the trade and portfolio data from a specific stock exchange, our essential aim in this study is to find who beats ${ }^{1}$ the market. We mainly look at investors who beat the market in a systematic way. To do so, we define the market beaters and beating conditions by using investor based data. Instead of market data, investor based data provides us stronger analyses. The most important advantage of using investor based data is that we can directly evaluate the performances of investors. Additionally, we can sub-categorize investor groups so we can easily deal with the details of each investor group.

In order to find who beats the market, first we eliminate investors who beat the market in a random way, not systematically. Here we benefit from the definition of strong form efficiency which states that the investors should not be able to beat the market consistently. To put it another way, if the market is efficient, no group of investors systematically can get higher returns than the market.

We first use "runs test" to put out the investors who breaks the randomness, so efficiency, in the market. As far as we know, this is the first paper that conducts runs test for each investor in order to see whether they provide randomness or not. Second, we investigate the beaters by sorting based on two criteria: beating length and beating performance. The beating length criterion is formed using the average length of runs. And the performance criterion is defined as the average value of the adjusted returns in positive runs. Finally, we examine whether the insiders' beating conditions differentiate from other investors in order to understand whether the market validates the strong form efficiency or not.

Using the trade record of a large sample of accounts in a specific stock exchange, we conduct several tests and make some analyses to determine who the market beaters are. We propose an approach for evaluating market beaters that are based upon both individual and institutional investors who have demonstrated abnormal skill in generating abnormal portfolio returns.

In order to find the beaters, first we eliminate investors whose gains are not random. We find that $13 \%$ of individual and $8 \%$ of institutional investors get returns in a non-random way. Then we look at the information about lengths of runs and our analysis indicates that the beating length of investors rises with increasing portfolio size and diversification, and shares of women, old adults, funds and foreigners. In addition to investigating for beating persistence, we analyze the beating performance of investors in our study. Here we show that the picture becomes reversed compared to beating length criteria. Finally, we compare the investors who have inside information with other investors to understand whether the market is efficient in the strong form or not. And the findings based on institutional investors remark that the insiders cannot be differentiated from other investors. Therefore, we end up with the evidence that there is strong form efficiency in Borsa İstanbul.

The outline of the study is as follows: Section 2 presents the detail of data. In Section 3 we introduce the methodology. Here we describe the basics and evaluation of market efficiency using the efficiency conditions. In Section 4, we provide estimation results, and the strong form of efficiency is investigated in Section 5. Finally, Section 6 contains the concluding remarks.

\section{Data}

The source of the data used in this study is Central Securities Depositories (MKK), where all the stocks listed on Borsa İstanbul are held electronically on behalf of investors. Number of stock investors in Turkey was 1,091,950 (as of the end of 2012) which is the composition of individual investors $(\# 1,086,400)$ and institutional investors (\# 5,550).

For this study, individuals who had portfolio amount more than TRY 1,000 ( USD 500) and traded at least once in between 2008 and 2012 are selected. We randomly select 25,000 individuals from these investors and the selection of the data is preserved under stratified random data characteristics such as the age, portfolio size distribution of the sample is the same in the population. For the institutional investors, we employ the data of all institutional investors (\# 5550). 
Our data is daily and consists of non-holiday regular weekdays (\# 1259 days) between 01.01 .2008 and 31.12.2012. All variables in this study are calculated daily contrary to the most of the literature which uses monthly data. Higher frequency is an advantage for us to have clearer picture for the performance of investors.

The data set includes daily positions (by stocks), daily sales and purchases for each stock in the portfolios for each investor. We also have information about some of the demographics (Age, nationality etc.) of investors. The sub-categories of investors are determined with respect to the information of these demographics.

\section{Methodology}

\subsection{Basics}

\subsubsection{Adjusted Return}

Daily raw returns of portfolios are defined as follows:

$r_{j t}^{\text {raw }}=\sum_{i=1}^{s_{j t}} p_{i j t} r_{i t}$

where $r_{i t}$ is the daily return for stock $i$ in day $t$. Also, $p_{i j t}$ represents the weight that was calculated by dividing the end-of-day $t$ market value for stock $i$ to the end-of-day $t$ market value of portfolio held by investor $j$. And $s_{j t}$ is the number of stocks held by investor $j$ at day $t$.

Market adjusted returns of individual $j$ are calculated daily as follows:

$r_{j t}=r_{j t}^{r a w}-r_{t}^{m}$

where $r_{t}^{m}$ denotes corresponding daily rate of return of the market (or main broad value stock index in the market).

Having calculated market adjusted daily returns in Equation (2) for each day $t \in[1,2, \ldots, 1259]$, we calculate the daily average return $\bar{r}_{t}$ for investors as:

$\bar{r}_{t}=\frac{1}{J} \sum_{j=1}^{J} r_{j t}$

where $J$ represents the total number of investors. Note that the "average return" is market adjusted as in Equation (2).

\subsubsection{Turnover}

To begin the analysis, following Barber and Odean (2000), we first define the turnover as follows:

Turnover $_{j t}=\frac{1}{2}\left(\frac{\text { TradedValue }_{j t}}{\overline{\text { PSize }}_{j}}\right)$

where TradedValue ${ }_{j t}$ is calculated as the total trade at day $t$ in terms of market value for each investor $j$. And, $\overline{P S i z e}_{j}$ represents the monthly average of end-of-day portfolio holdings in terms of market value for each investor $j$.

Having calculated market adjusted daily turnover in Equation (4) for each day $t \in[1,2, \ldots, 1259]$, we calculate the daily average turnover $\overline{\text { Turnover }}_{t}$ over investors as: 
$\overline{\text { Turnover }}_{t}=\left(\sum_{j=1}^{J}\right.$ Turnover $\left._{j t} / J\right)$

\subsubsection{Portfolio Size and Diversification}

We also define daily portfolio size for each investor as the end-of-day portfolio holdings. Portfolio diversification is calculated daily and refers to the number of stocks in a given portfolio.

\subsection{Market Beating}

\subsubsection{Efficiency Test}

Here, we investigate whether an investor beats the market in a continuous way. We are interested with the structure and distribution of consecutive days that each investor beats the market. To do so, we benefit from one of the most important implications of an efficient market is that the investors should not be able to beat the market consistently. To put it another way, if the market is efficient, no group of investors systematically can get higher returns than the market. Using similar notation in the literature, consecutive series of adjusted return movements without a sign reversal is defined as a run (Poshakwale, 1996). Hence the serried market beating (beatening) refers to positive (negative) run.

Since we can directly evaluate the performances of investors and also we can analyze each subcategory of investor groups, we chose to use investor based data instead of market data. So we can make stronger analyses. Here we imply runs test for each investor. As far as we investigate, this is the first paper that conducts runs test for each investor in order to see whether they beat the market in a random way or not. In order to determine whether the daily returns of an investor systematically higher than the daily market returns, we use non-parametric runs test. It does not require returns to have normal distribution. Observing the number of runs ${ }^{2}$, we can test the null hypothesis of randomness. To perform runs test, $(+)$ and $(-)$ are assigned to each positive and negative run respectively. Let $n_{+}$and $n$. be the sample sizes of positive and negative runs respectively. Also, $R$ is the total number of runs. Since the asymptotic distribution of runs is normal (Wald \& Wolfowitz, 1940), test statistics and critical points for the runs test are estimated with the normal distribution (Sheskin, 2000):

$$
z=\frac{\mathrm{R}-\mu_{R}}{\sigma_{R}}
$$

where

$$
\mu_{R}=\frac{2 n_{+} n_{-}}{n}+1, \quad \sigma_{R}=\sqrt{\frac{2 n_{+} n_{-}\left(2 n_{+} n_{-}-n\right)}{n^{2}(n-1)}} \text { and } n=n_{+}+n_{-}
$$

After we conduct the runs test, we find $z$ value for each investor. For investors who break the randomness according to the results of runs test, we defined them as inefficient investors ${ }^{3}$. Here, the term of inefficient is used to label investors who are able to trade in a way that identifies market inefficiencies, and as a result their trades contain sufficient information to get abnormal returns compared to the market (Coval, Hirshleifer, \& Shumway, 2005). So, the adjective form of inefficiency, which is used in almost all literature to define the situation in the market, is employed in this study just for simplicity to reveal investors who create inefficiency in the market.

\subsubsection{Direction of Inefficiency}

Using runs test helps to determine whether an investor provides randomness. However, if the randomness is not the case, we cannot separate investors who breaks randomness due to positive runs or negative runs. In order to solve this issue, we make use of average length of runs for each inefficient investor. In order to find the average value for each inefficient investor, we sum all runs' lengths of him/her. Here, if the run is positive (negative), then the sign before the length of the run is given as positive (negative). For 
example, the length of a run for 3 consecutive days of beating the market is +3 , but the length of a run for 4 consecutive days of beatening by the market is -4 .

\subsubsection{Magnitude of Inefficiency}

Another criterion to analyze inefficient investors is to look at the return performance of investors. Here we intend by return performance is to investigate the magnitude of returns. In this way, we aim to reach the information about investors who not only breaks the randomness but also get high abnormal returns. Here we concern with adjusted returns in positive runs for each inefficient investor. Then the average value for these returns is calculated for each inefficient investor. In such way, we can sort and compare inefficient investors by their return performances in the days they beat the market.

\section{Results}

\subsection{Results of Runs Test}

Histograms and $Q-Q$ plots in Figure 1 and 2 indicate that the distribution of runs test statistics for each type of investor seems to be normally distributed. Even though there is a debate ${ }^{4}$ on the normality test in the case of large sample size (Thadewald \& Büning, 2007) we present the result of normality test JarqueBera in Table 1 to compare the normality of distributions of runs tests. According to Jarque-Bera test results, the distribution of $z$ values for institutional investors is more normal compared to distribution for individual investors.

Figure 1. Distribution of Runs Test Statistics for Individual Investors

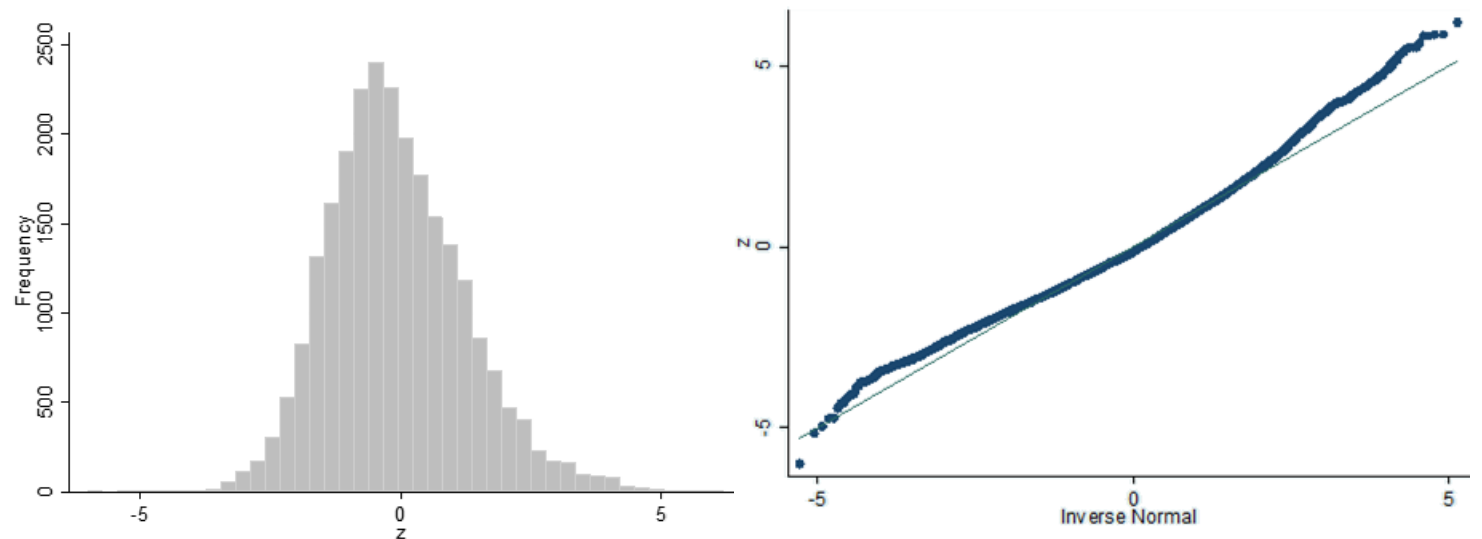

Note: The sub-figure on the left shows the histogram of runs test statistics for individual investors. And the sup-figure on the right illustrates the Q-Q plot.

Figure 2. Distribution of Runs Test Statistics for Institutional Investors
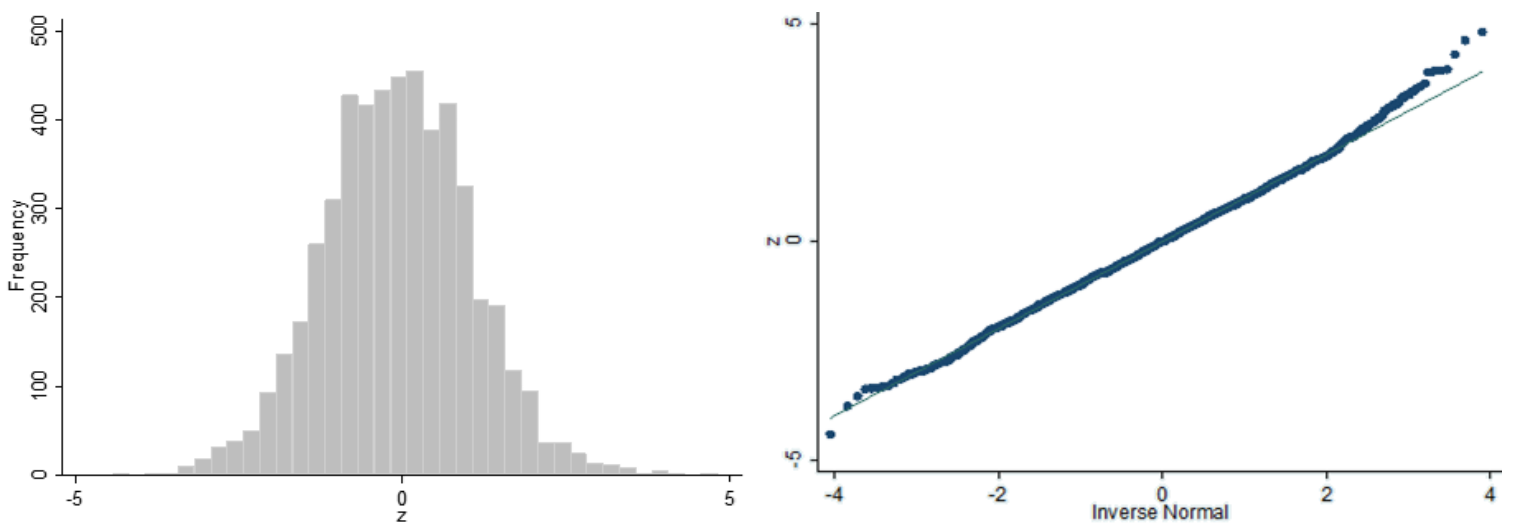

Note: The sub-figure on the left shows the histogram of runs test statistics for institutional investors. And the sup-figure on the right illustrates the Q-Q plot. 
Y. Varli

Table1. Descriptive Statistics of Runs Test

\begin{tabular}{|c|c|c|}
\hline Descriptives & Individual Investors & Institutional Investors \\
\hline Mean & -0.073 & -0.071 \\
\hline St. Dev. & 1.746 & 1.120 \\
\hline Median & -0.206 & -0.072 \\
\hline Skewness & 0.502 & 0.083 \\
\hline Kurtosis & 3.559 & 3.299 \\
\hline Jarque-Bera & 1374.756 & 25.336 \\
\hline
\end{tabular}

The results of runs test indicate that $z$ value of 3156 (out of 24965) individual investors and 391 (out of 5176) institutional investors are not in 95\% confidence interval. That is, $13 \%$ of individual and \%8 of institutional investors' daily adjusted returns are not distributed randomly. Therefore, they break the randomness in the market and from now on we call them as inefficient investors. Since, as far as we know, this is the first paper that conducts runs test using investor based data, we can not compare these numbers with ones in the literature. However, to provide an insight, some studies such as Fama (1991) and Poshakwale (1996) show that random walk theory does not fully work in the data.

\subsection{Results for Direction of Inefficiency}

\subsubsection{Relationship between Beating Length and State Variables}

We seek to gather information of inefficient investors using several state variables as the average length of runs increases. Here the information is collected from behavior of investors by using portfolio size, turnover and portfolio diversification. In order to show the relationship between the beating length and state variables of investors, we first sort the investors according to the average length of runs and then use the average values of variables for each investor. The average values of state variables for each run length quintile based on different type of investors are illustrated in Table 2 and 3.

Table 2. Relationship between Beating Length and State Variables for Inefficient Individual Investors

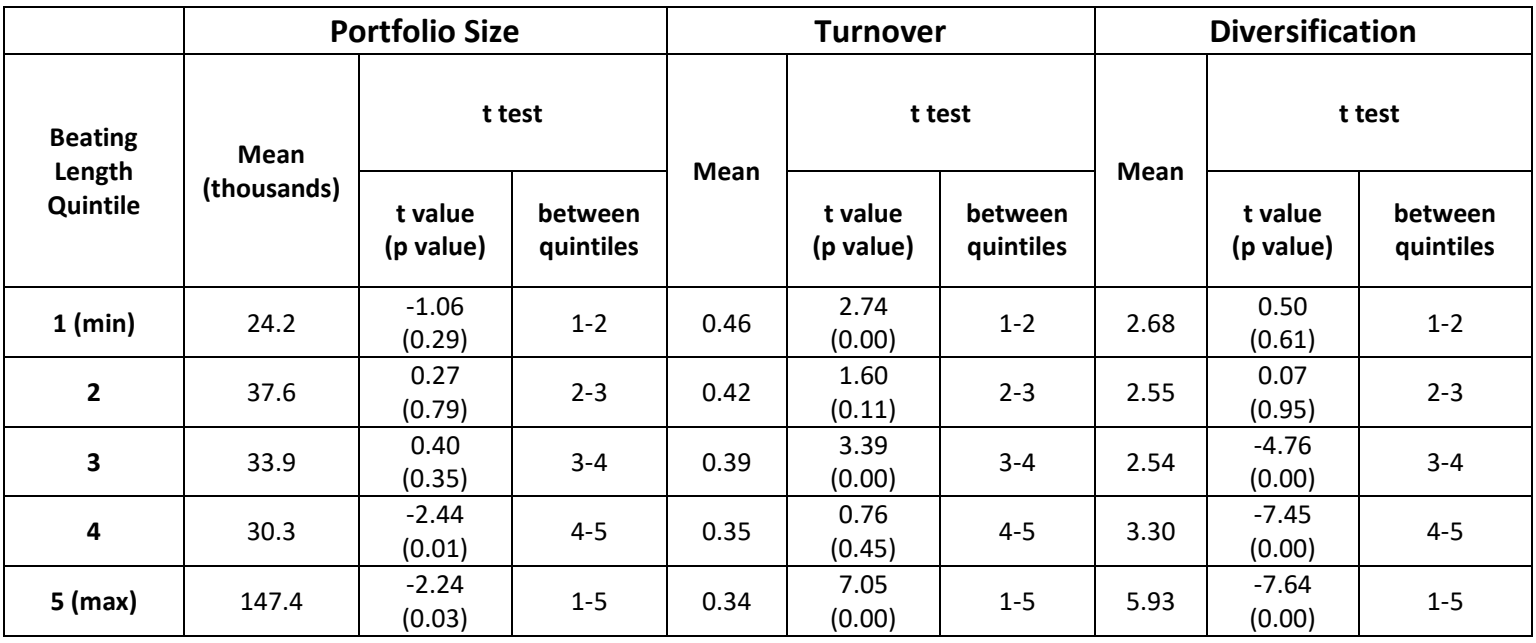

Note: The table presents the average values of state variables for each run length quintile based on inefficient individual investors. While quintile 1 contains investors with the lowest average run length, quintile 5 contains investors with the highest average run length. 
Table 3. Relationship between Beating Length and State Variables for Inefficient Institutional Investors

\begin{tabular}{|c|c|c|c|c|c|c|c|c|c|}
\hline \multirow{3}{*}{$\begin{array}{l}\text { Beating } \\
\text { Length } \\
\text { Quintile }\end{array}$} & \multicolumn{3}{|c|}{ Portfolio Size } & \multicolumn{3}{|c|}{ Turnover* } & \multicolumn{3}{|c|}{ Diversification } \\
\hline & \multirow{2}{*}{$\begin{array}{c}\text { Mean } \\
\text { (millions) }\end{array}$} & \multicolumn{2}{|c|}{$t$ test } & \multirow{2}{*}{ Mean } & \multicolumn{2}{|c|}{$t$ test } & \multirow{2}{*}{ Mean } & \multicolumn{2}{|c|}{$t$ test } \\
\hline & & $\begin{array}{c}t \text { value } \\
\text { ( } p \text { value) }\end{array}$ & $\begin{array}{l}\text { between } \\
\text { quintiles }\end{array}$ & & $\begin{array}{c}t \text { value } \\
\text { ( } p \text { value) }\end{array}$ & $\begin{array}{l}\text { between } \\
\text { quintiles }\end{array}$ & & $\begin{array}{c}t \text { value } \\
\text { ( } p \text { value) }\end{array}$ & $\begin{array}{l}\text { between } \\
\text { quintiles }\end{array}$ \\
\hline $1(\min )$ & 0.60 & $\begin{array}{l}-1.55 \\
(0.12)\end{array}$ & $1-2$ & 0.40 & $\begin{array}{c}2.94 \\
(0.00)\end{array}$ & $1-2$ & 1.88 & $\begin{array}{l}-0.97 \\
(0.33)\end{array}$ & $1-2$ \\
\hline 2 & 4.12 & $\begin{array}{c}0.02 \\
(0.99)\end{array}$ & $2-3$ & 0.28 & $\begin{array}{l}-0.44 \\
(0.66) \\
\end{array}$ & $2-3$ & 4.11 & $\begin{array}{l}-0.16 \\
(0.87) \\
\end{array}$ & $2-3$ \\
\hline 3 & 4.09 & $\begin{array}{l}-1.46 \\
(0.15) \\
\end{array}$ & $3-4$ & 0.29 & $\begin{array}{c}0.78 \\
(0.43) \\
\end{array}$ & $3-4$ & 4.43 & $\begin{array}{l}-1.52 \\
(0.13) \\
\end{array}$ & $3-4$ \\
\hline 4 & 8.41 & $\begin{array}{l}-0.92 \\
(0.36)\end{array}$ & $4-5$ & 0.26 & $\begin{array}{c}1.30 \\
(0.19)\end{array}$ & $4-5$ & 9.52 & $\begin{array}{l}-1.43 \\
(0.15)\end{array}$ & $4-5$ \\
\hline $5(\max )$ & 12.5 & $\begin{array}{l}-2.75 \\
(0.00)\end{array}$ & $1-5$ & 0.21 & $\begin{array}{c}4.10 \\
(0.00)\end{array}$ & $3-5$ & 15.21 & $\begin{array}{l}-5.39 \\
(0.00)\end{array}$ & $1-5$ \\
\hline
\end{tabular}

Note: The table presents the average values of state variables for each run length quintile based on inefficient institutional investors. While quintile 1 contains investors with the lowest average run length, quintile 5 contains investors with the highest average run length.

Records of inefficient investors are sorted into quintiles based on the value of average run length. Quintile 1 contains investors with the lowest average run length; quintile 5 contains investors with the highest average run length. The findings based on both individual and institutional investors indicate that as the investors' average length of runs rises, the average value of their portfolio size and diversification increase and the turnover decreases. That is, the longer the beating, the higher the portfolio size and diversification but the lower the turnover. In addition, Table 2 and 3 show that the differences between average values of state variables from Highest and Lowest beating length quintiles are significant for both inefficient individual and institutional investor types. These results are compatible with the literature (Van Horne, Blume, \& Friend, 1975; Ferris, Haugen, \& Makhija, 1988; Barber \& Odean, 2000; Grinblatt \& Keloharju, 2001; Bauer, Cosemans, \& Eichholtz, 2007) which state in general that investors who beat the market hold larger accounts with lower turnover and more diversified portfolio.

\subsubsection{Relationship between Beating Length and Descriptive Variables}

We also collect the descriptive information of inefficient investors and illustrate how the direction of inefficiency is related by these descriptive variables. First, the distributions of sex by beating length for inefficient individual investors are presented in Table 4. The results indicate that the share of women in the inefficient individual investors increases as beating length rises. That is, women are more successful compared to men in terms of increasing their share as length of beating goes up. This finding confirms Bauer et al. (2007) which indicates that female investors are more likely to be persistent winners than male investors.

Table 4. Distribution of Sex by Beating Length for Inefficient Individual Investors

\begin{tabular}{|c|c|c|c|c|c|c|}
\hline \multirow[b]{3}{*}{ Beating Length Quintile } & \multicolumn{3}{|c|}{ Female } & \multicolumn{3}{|c|}{ Male } \\
\hline & \multirow[b]{2}{*}{ Proportion } & \multicolumn{2}{|c|}{ Proportion test } & \multirow[b]{2}{*}{ Proportion } & \multicolumn{2}{|c|}{ Proportion test } \\
\hline & & $\begin{array}{l}z \text { value } \\
\text { ( } p \text { value) }\end{array}$ & $\begin{array}{l}\text { between } \\
\text { quintiles }\end{array}$ & & $\begin{array}{l}z \text { value } \\
\text { ( } p \text { value) }\end{array}$ & $\begin{array}{l}\text { between } \\
\text { quintiles }\end{array}$ \\
\hline 2 & 0.19 & $-2.31(0.02)$ & $2-3$ & 0.81 & $2.31(0.02)$ & $2-3$ \\
\hline 3 & 0.24 & $-0.92(0.36)$ & $3-4$ & 0.76 & $0.92(0.36)$ & $3-4$ \\
\hline
\end{tabular}

Note: The table presents the share distribution of sex for each run length quintile based on inefficient individual investors. While quintile 1 contains investors with the lowest average run length, quintile 5 contains investors with the highest average run length. 
Table 5. Distribution of Age by Beating Length for Inefficient Individual Investors

\begin{tabular}{|c|c|c|c|c|c|c|c|c|c|}
\hline \multirow{3}{*}{$\begin{array}{c}\text { Beating } \\
\text { Length } \\
\text { Quintile }\end{array}$} & \multicolumn{3}{|c|}{ Young (18-35) } & \multicolumn{3}{|c|}{ Middle Age (36-55) } & \multicolumn{3}{|c|}{ Old (55+) } \\
\hline & \multirow[b]{2}{*}{ Proportion } & \multicolumn{2}{|c|}{$t$ test } & \multirow[b]{2}{*}{ Proportion } & \multicolumn{2}{|c|}{ t test } & \multirow[b]{2}{*}{ Proportion } & \multicolumn{2}{|c|}{ t test } \\
\hline & & $\begin{array}{c}\text { z value } \\
\text { (p } \\
\text { value) }\end{array}$ & $\begin{array}{l}\text { between } \\
\text { quintiles }\end{array}$ & & $\begin{array}{c}\text { z value } \\
\text { ( } p \\
\text { value) }\end{array}$ & $\begin{array}{l}\text { between } \\
\text { quintiles }\end{array}$ & & $\begin{array}{c}\text { z value } \\
\text { ( } p \\
\text { value) }\end{array}$ & $\begin{array}{l}\text { between } \\
\text { quintiles }\end{array}$ \\
\hline 1 (min) & 0.27 & $\begin{array}{c}0.84 \\
(0.40) \\
\end{array}$ & $1-2$ & 0.60 & $\begin{array}{c}-0.29 \\
(0.77) \\
\end{array}$ & $1-2$ & 0.12 & $\begin{array}{c}-0.67 \\
(0.50) \\
\end{array}$ & $1-2$ \\
\hline 2 & 0.25 & $\begin{array}{c}1.45 \\
(0.15) \\
\end{array}$ & $2-3$ & 0.61 & $\begin{array}{c}0.85 \\
(0.40)\end{array}$ & $2-3$ & 0.14 & $\begin{array}{c}-2.74 \\
(0.00) \\
\end{array}$ & $2-3$ \\
\hline 3 & 0.22 & $\begin{array}{c}2.82 \\
(0.00)\end{array}$ & $3-4$ & 0.58 & $\begin{array}{c}-1.91 \\
(0.06)\end{array}$ & $3-4$ & 0.20 & $\begin{array}{c}-0.45 \\
(0.65)\end{array}$ & $3-4$ \\
\hline 4 & 0.16 & $\begin{array}{l}-1.80 \\
(0.07) \\
\end{array}$ & $4-5$ & 0.63 & $\begin{array}{c}1.42 \\
(0.16) \\
\end{array}$ & $4-5$ & 0.21 & $\begin{array}{c}0.00 \\
(0.99) \\
\end{array}$ & $4-5$ \\
\hline $5(\max )$ & 0.20 & $\begin{array}{c}2.75 \\
(0.00) \\
\end{array}$ & $1-5$ & 0.59 & $\begin{array}{c}0.18 \\
(0.86)\end{array}$ & $3-5$ & 0.21 & $\begin{array}{l}-3.39 \\
(0.00)\end{array}$ & $1-5$ \\
\hline
\end{tabular}

Note: The table presents the share distribution of age for each run length quintile based on inefficient individual investors. While quintile 1 contains investors with the lowest average run length, quintile 5 contains investors with the highest average run length.

Table 6. Distribution of District by Beating Length for Individual Investors

\begin{tabular}{|c|c|c|c|c|c|c|}
\hline & \multicolumn{3}{|c|}{ Marmara } & \multirow{2}{*}{ Other } \\
\cline { 6 - 7 } $\begin{array}{c}\text { Beating } \\
\text { Length } \\
\text { Quintile }\end{array}$ & \multirow{2}{*}{ Proportion } & \multicolumn{2}{|c|}{$\begin{array}{c}\text { Proportion test } \\
\text { z value } \\
\text { (p value) }\end{array}$} & $\begin{array}{c}\text { Petween } \\
\text { quintiles }\end{array}$ & Proportion & \multicolumn{2}{|c|}{$\begin{array}{c}\text { Z value } \\
\text { (p value) }\end{array}$} & $\begin{array}{c}\text { Petween } \\
\text { quintiles }\end{array}$ \\
\hline $\mathbf{1}$ (min) & 0.48 & $\begin{array}{c}0.68 \\
(0.50)\end{array}$ & $1-2$ & 0.52 & $\begin{array}{c}-0.68 \\
(0.50)\end{array}$ & $1-2$ \\
\hline $\mathbf{2}$ & 0.46 & $\begin{array}{c}0.48 \\
(0.63)\end{array}$ & $2-3$ & 0.54 & $\begin{array}{c}-0.48 \\
(0.63)\end{array}$ & $2-3$ \\
\hline $\mathbf{3}$ & 0.45 & $\begin{array}{c}0.60 \\
(0.55)\end{array}$ & $3-4$ & 0.55 & $\begin{array}{c}-0.60 \\
(0.55)\end{array}$ & $3-4$ \\
\hline $\mathbf{4}$ & 0.43 & $\begin{array}{c}-2.82 \\
(0.00)\end{array}$ & $4-5$ & 0.57 & $\begin{array}{c}2.82 \\
(0.00)\end{array}$ & $4-5$ \\
\hline $\mathbf{5}$ (max) & 0.52 & $\begin{array}{c}-1.08 \\
(0.28)\end{array}$ & $1-5$ & 0.48 & $\begin{array}{c}1.08 \\
(0.28)\end{array}$ & $1-5$ \\
\hline
\end{tabular}

Note: The table presents the share distribution of district for each run length quintile based on inefficient individual investors. While quintile 1 contains investors with the lowest average run length, quintile 5 contains investors with the highest average run length.

The age distribution by beating length for inefficient individual investors is illustrated in Table 5 . The numbers in the table state that the share of middle age group remains nearly same. However, the share of young (old) adult group's share decreases (increases) significantly as the average length of runs rises. That is, young and older adults switch their shares as the beating length increases. This is similar to findings in Korniotis and Kumar (2011) which deduces that older investors, knowledgeable about investment, have inferior stock selection ability.

Table 6 illustrates the share of inefficient individual investors' districts. It also shows the information of districts of inefficient investors with respect to changing beating length. Half of the individual investors are from Marmara district and the rest are from other districts. This is parallel to the population structure in Turkey. When we look at the district information of inefficient individual investors, we reach that the overall picture does not have a significant change as the beating length changes ${ }^{5}$. 

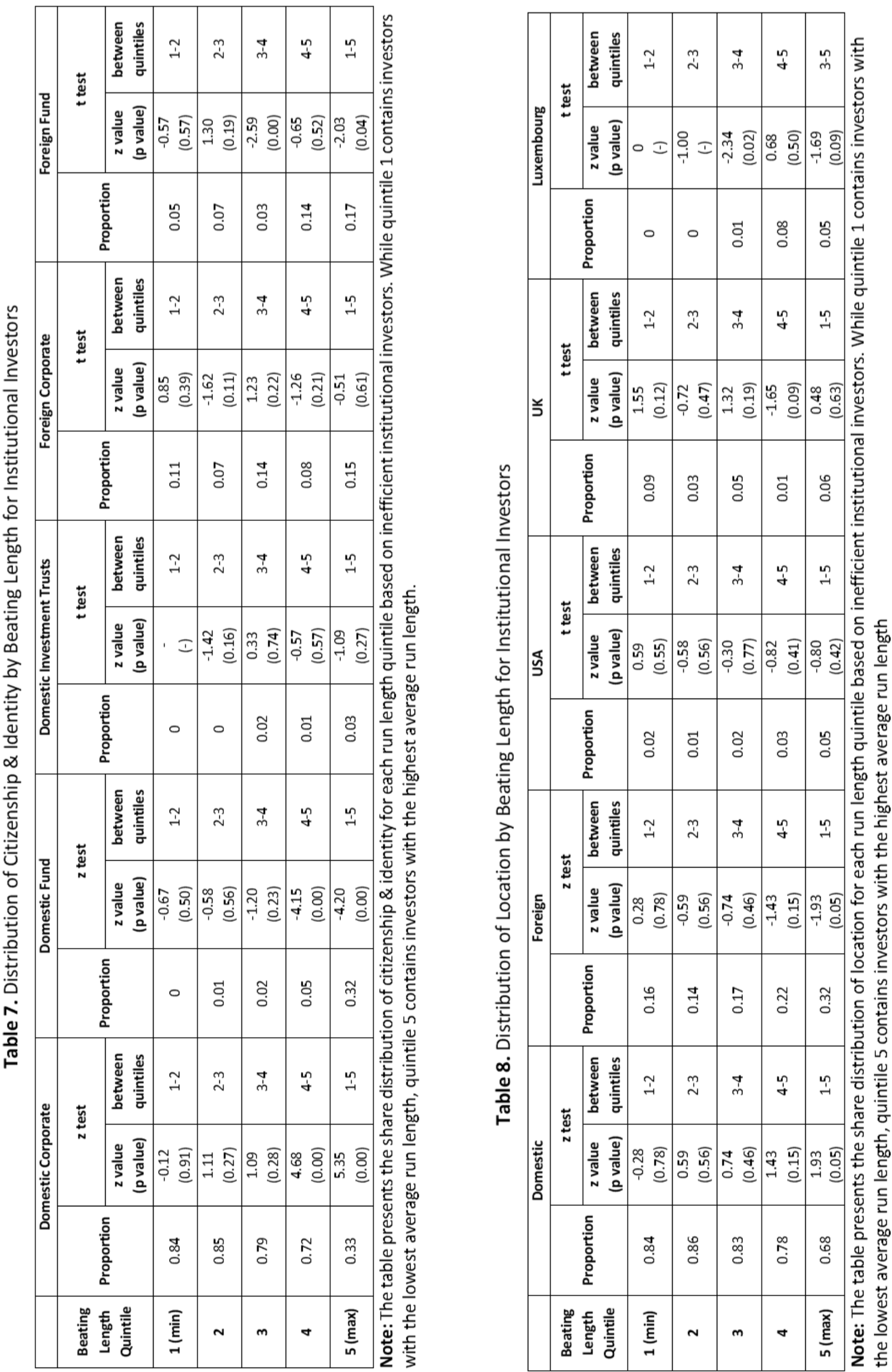
Besides of the analyses for individual investors, there are also other types of descriptive information for institutional investors. For example, it is shown that how the distribution of citizenship \& identity changes with rising beating length for inefficient institutional investors in Table 7. According to the results indicated in the table, share of the funds in the inefficient investors increases from $5 \%$ to nearly $50 \%$ as the average length of runs rises. This change is mainly caused by the dramatic increase in the share of domestic funds. While the share of domestic funds is nearly zero in the lowest beating length, the share significantly increases to $32 \%$ in the highest beating length. The increase in the share of foreign investors is also significant. In addition, the share of domestic corporates decreases in a significant way while the beating length rises. All these results indicate that the funds especially domestic funds in Borsa İstanbul are better than other type of institutional investors in beating the market systematically.

The distribution of country location by beating length for inefficient institutional investors is presented in Table 8. For instance, the results for the inefficient institutional investors indicate that the share of foreign investors increases as the beating length rises. The foreigners double their shares significantly as moving from 1st quintile to 5th quintile of average run length. This result is in accord with Grinblatt and Keloharju (2000) and Barber et al. (2009) which broadly find that foreign investors outperform compared to other investors. Grinblatt and Keloharju (2000) attributes this situation to some specifications of foreign investors such as tending to be momentum investors, buying past winning stocks and selling past losers. In order to analyze the increase of the share of foreigners in the inefficient investors, we also demonstrate in Table 8 the breakdown of shares of foreign investors that are addressed in top three foreign countries; namely USA, UK and Luxembourg. As the beating length increases, most notable change is observed for the investors from Luxembourg.

\subsection{Results for Magnitude of Inefficiency}

\subsubsection{Relationship between Beating Performance and State Variables}

Similar to the Section 4.2.1., we use quintile analysis. In order to highlight the relationship between the beating performance and several state variables, we sort the investors according to the average return in positive runs and divide them into quintiles. The average values of variables for positive adjusted return quintiles based on different type of investors are illustrated in Table 9 and 10.

Table 9. Relationship between Beating Performance and State Variables for Inefficient Individual Investors

\begin{tabular}{|c|c|c|c|c|c|c|c|c|c|}
\hline \multirow{3}{*}{$\begin{array}{c}\text { Beating } \\
\text { Performance } \\
\text { Quintile }\end{array}$} & \multicolumn{3}{|c|}{ Portfolio Size } & \multicolumn{3}{|c|}{ Turnover } & \multicolumn{3}{|c|}{ Diversification } \\
\hline & \multirow{2}{*}{$\begin{array}{c}\text { Mean } \\
\text { (thousands) }\end{array}$} & \multicolumn{2}{|c|}{$t$ test } & \multirow{2}{*}{ Mean } & \multicolumn{2}{|c|}{$t$ test } & \multirow{2}{*}{ Mean } & \multicolumn{2}{|c|}{$t$ test } \\
\hline & & $\begin{array}{c}t \text { value } \\
\text { ( } p \text { value) }\end{array}$ & $\begin{array}{l}\text { between } \\
\text { quintiles }\end{array}$ & & $\begin{array}{c}t \text { value } \\
\text { ( } p \text { value) }\end{array}$ & $\begin{array}{l}\text { between } \\
\text { quintiles }\end{array}$ & & $\begin{array}{c}\text { t value } \\
\text { ( } p \text { value) }\end{array}$ & $\begin{array}{l}\text { between } \\
\text { quintiles }\end{array}$ \\
\hline $1(\min )$ & 113.3 & $\begin{array}{c}1.53 \\
(0.13) \\
\end{array}$ & $1-2$ & 0.21 & $\begin{array}{l}-8.75 \\
(0.00) \\
\end{array}$ & $1-2$ & 8.34 & $\begin{array}{l}10.00 \\
(0.00)\end{array}$ & $1-2$ \\
\hline 2 & 48.5 & $\begin{array}{c}1.30 \\
(0.19) \\
\end{array}$ & $2-3$ & 0.35 & $\begin{array}{c}-4.21 \\
(0.00) \\
\end{array}$ & $2-3$ & 3.66 & $\begin{array}{c}5.28 \\
(0.00) \\
\end{array}$ & $2-3$ \\
\hline 3 & 30.6 & $\begin{array}{l}-0.99 \\
(0.32)\end{array}$ & $3-4$ & 0.41 & $\begin{array}{l}-2.57 \\
(0.01)\end{array}$ & $3-4$ & 2.61 & $\begin{array}{c}3.83 \\
(0.00)\end{array}$ & $3-4$ \\
\hline 4 & 62.1 & $\begin{array}{c}1.24 \\
(0.21)\end{array}$ & $4-5$ & 0.44 & $\begin{array}{l}-1.85 \\
(0.06) \\
\end{array}$ & $4-5$ & 2.02 & $\begin{array}{l}-0.13 \\
(0.90) \\
\end{array}$ & $4-5$ \\
\hline $5(\max )$ & 25.4 & $\begin{array}{c}2.63 \\
(0.00)\end{array}$ & $1-5$ & 0.47 & $\begin{array}{l}-17.69 \\
(0.00)\end{array}$ & $1-5$ & 2.03 & $\begin{array}{l}17.11 \\
(0.00)\end{array}$ & $1-5$ \\
\hline
\end{tabular}

Note: The table presents the average values of state variables for each return performance quintile based on inefficient individual investors. While quintile 1 contains investors with the lowest average adjusted return; quintile 5 contains investors with the highest average adjusted return. 
Records of inefficient investors are sorted into quintiles based on the value of average adjusted return in positive runs. Quintile 1 contains investors with the lowest average adjusted return; quintile 5 contains investors with the highest average adjusted return. The results based on both individual and institutional investors indicate that as the investors' average adjusted return rises, the average value of their portfolio size and diversification decrease and the turnover increases. That is, the better the return performance, the lower the portfolio size and diversification but the higher the turnover. Table 9 and 10 also demonstrate that the differences between average values of state variables from Highest and Lowest beating performance quintiles are significant for both inefficient individual and institutional investor types. This changing picture compared to beating length analysis indicates that investors in Borsa Istanbul choose between length or magnitude of returns.

Table 10. Relationship between Beating Performance and State Variables for Inefficient Institutional Investors

\begin{tabular}{|c|c|c|c|c|c|c|c|c|c|}
\hline \multirow{3}{*}{$\begin{array}{c}\text { Beating } \\
\text { Performance } \\
\text { Quintile }\end{array}$} & \multicolumn{3}{|c|}{ Portfolio Size } & \multicolumn{3}{|c|}{ Turnover* } & \multicolumn{3}{|c|}{ Diversification } \\
\hline & \multirow{2}{*}{$\begin{array}{c}\text { Mean } \\
\text { (millions) }\end{array}$} & \multicolumn{2}{|c|}{$t$ test } & \multirow{2}{*}{ Mean } & \multicolumn{2}{|c|}{$t$ test } & \multirow{2}{*}{ Mean } & \multicolumn{2}{|c|}{$t$ test } \\
\hline & & $\begin{array}{c}\text { t value } \\
\text { ( } p \text { value) }\end{array}$ & $\begin{array}{l}\text { between } \\
\text { quintiles }\end{array}$ & & $\begin{array}{c}t \text { value } \\
\text { ( } p \text { value) }\end{array}$ & $\begin{array}{l}\text { between } \\
\text { quintiles }\end{array}$ & & $\begin{array}{c}t \text { value } \\
\text { ( } p \text { value) }\end{array}$ & $\begin{array}{l}\text { between } \\
\text { quintiles }\end{array}$ \\
\hline 1 (min) & 18.1 & $\begin{array}{c}3.20 \\
(0.00) \\
\end{array}$ & $1-2$ & 0.11 & $\begin{array}{l}-3.42 \\
(0.00) \\
\end{array}$ & $1-2$ & 25.2 & $\begin{array}{c}3.44 \\
(0.00) \\
\end{array}$ & $1-2$ \\
\hline 2 & 2.87 & $\begin{array}{l}-0.11 \\
(0.91)\end{array}$ & $2-3$ & 0.23 & $\begin{array}{l}-1.18 \\
(0.24)\end{array}$ & $2-3$ & 8.57 & $\begin{array}{c}2.11 \\
(0.04)\end{array}$ & $2-3$ \\
\hline 3 & 3.05 & $\begin{array}{l}-1.10 \\
(0.27) \\
\end{array}$ & $3-4$ & 0.27 & $\begin{array}{l}-1.12 \\
(0.27) \\
\end{array}$ & $3-4$ & 3.17 & $\begin{array}{c}1.58 \\
(0.12) \\
\end{array}$ & $3-4$ \\
\hline 4 & 5.34 & $\begin{array}{c}0.83 \\
(0.41)\end{array}$ & $4-5$ & 0.32 & $\begin{array}{l}-1.98 \\
(0.04)\end{array}$ & $4-5$ & 1.70 & $\begin{array}{l}-0.86 \\
(0.39)\end{array}$ & $4-5$ \\
\hline $5(\max )$ & 3.35 & $\begin{array}{c}3.72 \\
(0.00)\end{array}$ & $1-5$ & 0.39 & $\begin{array}{l}-7.72 \\
(0.00)\end{array}$ & $1-5$ & 2.90 & $\begin{array}{c}6.47 \\
(0.00)\end{array}$ & $1-5$ \\
\hline
\end{tabular}

Note: The table presents the average values of state variables for each return performance quintile based on inefficient institutional investors. While quintile 1 contains investors with the lowest average adjusted return; quintile 5 contains investors with the highest average adjusted return.

\subsubsection{Relationship between Beating Performance and Descriptive Variables}

Using the descriptive information of inefficient investors, we present the distributions of sex by beating performance for inefficient individual investors are presented in Table 11. We find that the share of men in the inefficient individual investors increases significantly as the beating performance rises and vice versa for the share of women.

Table 11. Distribution of Sex by Beating Performance for Inefficient Individual Investors

\begin{tabular}{|c|c|c|c|c|c|c|}
\hline \multirow{3}{*}{$\begin{array}{c}\text { Beating Performance } \\
\text { Quintile }\end{array}$} & \multicolumn{3}{|c|}{ Female } & \multicolumn{3}{|c|}{ Male } \\
\hline & \multirow[b]{2}{*}{ Proportion } & \multicolumn{2}{|c|}{ Proportion test } & \multirow[b]{2}{*}{ Proportion } & \multicolumn{2}{|c|}{ Proportion test } \\
\hline & & $\begin{array}{l}z \text { value } \\
\text { ( } p \text { value) }\end{array}$ & $\begin{array}{l}\text { between } \\
\text { quintiles }\end{array}$ & & $\begin{array}{l}z \text { value } \\
\text { ( } p \text { value) }\end{array}$ & between quintiles \\
\hline 1 (min) & 0.30 & $0.98(0.33)$ & $1-2$ & 0.70 & $-0.98(0.33)$ & $1-2$ \\
\hline 2 & 0.27 & $1.80(0.07)$ & $2-3$ & 0.73 & $-1.80(0.07)$ & $2-3$ \\
\hline 5 (max) & 0.16 & $5.83(0.00)$ & $1-5$ & 0.84 & $-5.83(0.00)$ & $1-5$ \\
\hline
\end{tabular}

Note: The table presents the share distribution of sex for each return performance quintile based on inefficient individual investors. While quintile 1 contains investors with the lowest average run length, quintile 5 contains investors with the highest average run length. 
The age distribution by beating performance for inefficient individual investors is illustrated in Table 12. The table states that the share of middle age group remains nearly same. However, the share of young (old) adult group's share increases (decreases) significantly as the return performance rises. With summing up the findings in Section 4.2.2., we reach that while older investors are good at beating continuity; young investors are better in beating return performance.

To understand the beating performance of individual investors, we use another descriptive variable, namely district. Table 13 illustrates the information of districts of inefficient investors with respect to changing beating performance. Half of the individual investors are from Marmara district and the rest are from other districts. This is parallel to the population structure in Turkey. When we look at the inefficient individual investors, the results are similar to the case of beating length that the overall picture does not change as the beating performance changes. However, the share of investors located on Marmara now decreases in $10 \%$ significant level.

Table 12. Distribution of Age by Beating Performance for Inefficient Individual Investors

\begin{tabular}{|c|c|c|c|c|c|c|c|c|c|}
\hline \multirow[b]{3}{*}{$\begin{array}{c}\text { Beating } \\
\text { Performance } \\
\text { Quintile }\end{array}$} & \multicolumn{3}{|c|}{ Young (18-35) } & \multicolumn{3}{|c|}{ Middle Age (36-55) } & \multicolumn{3}{|c|}{ Old $(55+)$} \\
\hline & \multirow[b]{2}{*}{ Proportion } & \multicolumn{2}{|c|}{ t test } & \multirow[b]{2}{*}{ Proportion } & \multicolumn{2}{|c|}{ t test } & \multirow[b]{2}{*}{ Proportion } & \multicolumn{2}{|c|}{ t test } \\
\hline & & $\begin{array}{l}\text { z value } \\
\text { ( } p \\
\text { value) }\end{array}$ & $\begin{array}{l}\text { between } \\
\text { quintiles }\end{array}$ & & $\begin{array}{l}z \text { value } \\
\text { ( } p \text { value) }\end{array}$ & $\begin{array}{l}\text { between } \\
\text { quintiles }\end{array}$ & & $\begin{array}{l}\text { z value } \\
\text { (p } \\
\text { value) }\end{array}$ & $\begin{array}{l}\text { between } \\
\text { quintiles }\end{array}$ \\
\hline 1 (min) & 0.10 & $\begin{array}{l}-3.51 \\
(0.00)\end{array}$ & $1-2$ & 0.60 & $\begin{array}{l}-0.15 \\
(0.88)\end{array}$ & $1-2$ & 0.30 & $\begin{array}{c}3.01 \\
(0.50)\end{array}$ & $1-2$ \\
\hline 2 & 0.18 & $\begin{array}{l}-0.40 \\
(0.69)\end{array}$ & $2-3$ & 0.60 & $\begin{array}{c}0.30 \\
(0.76)\end{array}$ & $2-3$ & 0.22 & $\begin{array}{c}0.02 \\
(0.98)\end{array}$ & $2-3$ \\
\hline 3 & 0.19 & $\begin{array}{c}-1.94 \\
(0.05)\end{array}$ & $3-4$ & 0.59 & $\begin{array}{l}-1.24 \\
(0.21)\end{array}$ & $3-4$ & 0.22 & $\begin{array}{c}3.66 \\
(0.00)\end{array}$ & $3-4$ \\
\hline 4 & 0.23 & $\begin{array}{c}-3.69 \\
(0.00)\end{array}$ & $4-5$ & 0.62 & $\begin{array}{c}1.84 \\
(0.07)\end{array}$ & $4-5$ & 0.14 & $\begin{array}{c}2.30 \\
(0.02)\end{array}$ & $4-5$ \\
\hline $5(\max )$ & 0.32 & $\begin{array}{l}-8.46 \\
(0.00)\end{array}$ & $1-5$ & 0.58 & $\begin{array}{c}0.61 \\
(0.54)\end{array}$ & $3-5$ & 0.10 & $\begin{array}{c}8.75 \\
(0.00)\end{array}$ & $1-5$ \\
\hline
\end{tabular}

Note: The table presents the share distribution of age for each return performance quintile based on inefficient individual investors. While quintile 1 contains investors with the lowest average run length, quintile 5 contains investors with the highest average run length.

Table 13. Distribution of District by Beating Performance for Inefficient Individual Investors

\begin{tabular}{|c|c|c|c|c|c|c|}
\hline & \multicolumn{3}{|c|}{ Marmara } & \multicolumn{3}{|c|}{ Other } \\
\hline \multirow{2}{*}{$\begin{array}{c}\text { Beating } \\
\text { Length } \\
\text { Quintile }\end{array}$} & \multirow{2}{*}{ Proportion } & \multicolumn{2}{|c|}{ Proportion test } & \multirow{2}{*}{ Proportion test } \\
\cline { 3 - 4 } & $\begin{array}{c}\mathbf{z} \text { value } \\
\text { (p value) }\end{array}$ & $\begin{array}{c}\text { between } \\
\text { quintiles }\end{array}$ & Proportion & $\begin{array}{c}\text { z value } \\
\text { (p value) }\end{array}$ & $\begin{array}{c}\text { between } \\
\text { quintiles }\end{array}$ \\
\hline $\mathbf{1}$ (min) & 0.51 & $\begin{array}{c}1.56 \\
(0.12)\end{array}$ & $1-2$ & 0.49 & $\begin{array}{c}-1.56 \\
(0.12)\end{array}$ & $1-2$ \\
\hline $\mathbf{2}$ & 0.46 & $\begin{array}{c}-0.77 \\
(0.44)\end{array}$ & $2-3$ & 0.54 & $\begin{array}{c}0.77 \\
(0.44)\end{array}$ & $2-3$ \\
\hline $\mathbf{3}$ & 0.48 & $\begin{array}{c}1.86 \\
(0.62)\end{array}$ & $3-4$ & 0.52 & $\begin{array}{c}-1.86 \\
(0.62)\end{array}$ & $3-4$ \\
\hline $\mathbf{4}$ & 0.43 & $\begin{array}{c}-0.80 \\
(0.42)\end{array}$ & $4-5$ & 0.57 & $\begin{array}{c}0.80 \\
(0.42)\end{array}$ & $4-5$ \\
\hline $\mathbf{5}$ (max) & 0.45 & $\begin{array}{c}1.90 \\
(0.06)\end{array}$ & $1-5$ & 0.55 & $\begin{array}{c}-1.90 \\
(0.06)\end{array}$ & $1-5$ \\
\hline
\end{tabular}

Note: The table presents the share distribution of district for each return performance quintile based on inefficient individual investors. While quintile 1 contains investors with the lowest average run length, quintile 5 contains investors with the highest average run length. 
In addition to distributions of descriptive variables for individual investors, we analyze the relationship between beating performance and some descriptive variables for institutional investors. First, the distribution of citizenship \& identity with rising beating performance for inefficient institutional investors is presented in Table 14. According to the results indicated in the table, the share of funds in inefficient institutional investors decreases from $61 \%$ to $7 \%$ as the average return performance rises. This increase is dramatic especially for the domestic funds. While the share of domestic funds is $44 \%$ in the lowest beating performance quintile, the share becomes zero in the highest beating performance quintile. For the variable of citizenship \& identity, the picture of beating performance distribution is almost reverse of the picture of beating length distribution.

For another analysis, the distribution of country location by beating performance for inefficient institutional investors is represented in Table 15. The results for the inefficient institutional investors in the table indicate that the highest share of foreign investors is placed on the first quintile of beating performance. In order to analyze the increase of the share of foreigners in the inefficient investors, we also demonstrate the breakdown of foreign investors in Table 15. As the beating length increases, most notable change is observed for the investors from Luxembourg. While the share of Luxembourg is $44 \%$ in the lowest beating performance quintile, the share becomes zero in the highest beating performance quintile. Increasing share of investors from United Kingdom is also another remarkable change as the beating performance rises.

\subsection{Strong form Efficiency}

One of the things which have come up for discussion in recent years, especially after the recent financial crisis, is Efficient Market Hypothesis (Malkiel \& Fama, 1970). There are several studies (Basu, 1977; Fama, 1991; Borges, 2010) that are trying to question the relevance of this hypothesis.

As Fama (1970) states 'A market in which prices always "fully reflect" available information is called "efficient"', Fama (1970) suggests three forms of market efficiency that represent the different information sets used to predict price changes in the market. First form which is called "weak-form" implies that the market is efficient, reflecting all market information. Here, there is an assumption that successive prices changes are independently and identically distributed. Second, semi-strong form implies that the market reflects all publicly available information. Semi-strong form also incorporates the weak-form of market efficiency. The last one, strong form of market efficiency expands the information set to all available information, including private information.

Most of the literature for the market efficiency emphasizes the role of informational efficiency. While Fama (1970) has an evidence of weak form and semi-strong form efficiencies, Fama (1991) states the stronger form of efficiency. Since the strong form of efficiency incorporates the all other forms and our data set provides us to investigate the strong form of efficiency, we decide to utilize and test the strong form of efficiency in this study. 


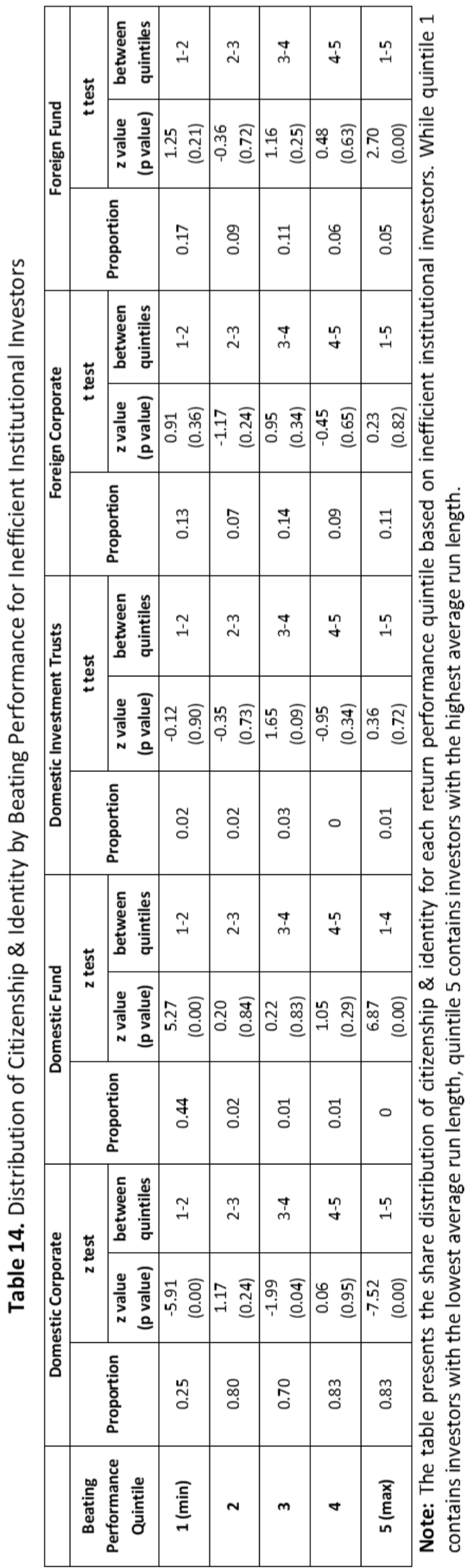




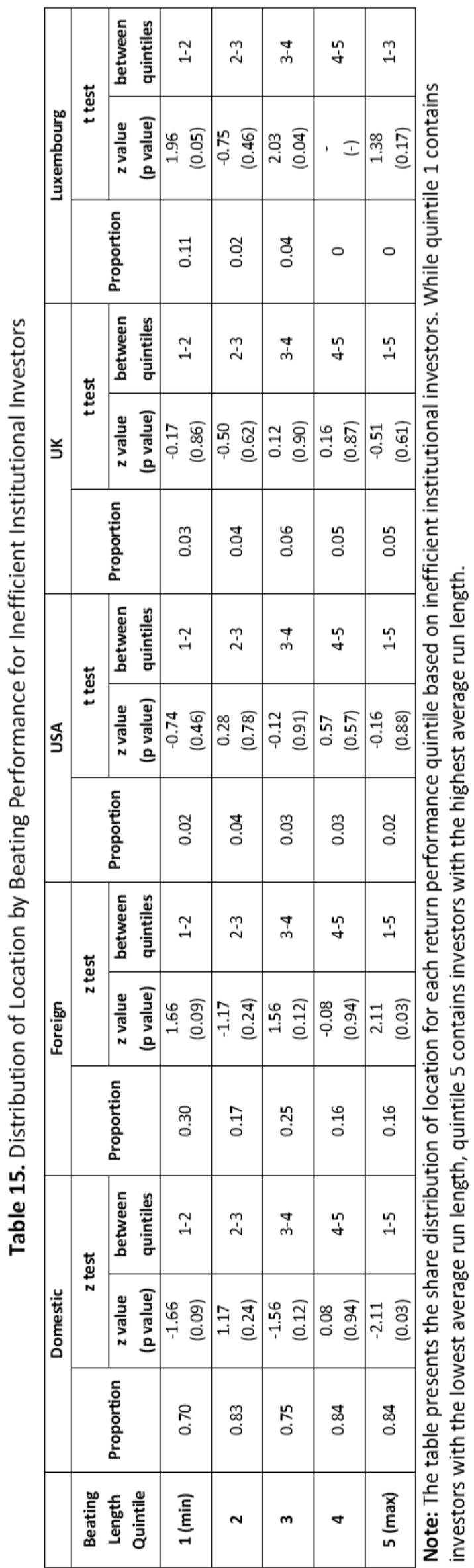


Strong from of market efficiency implies that prices reflect all private (inside) information. This form of efficiency investigates whether investors can earn abnormal profits by trading on private information. Testing for strong form of efficiency focuses on the groups of investors with excess information named "insiders", to investigate whether any private information can be used to generate abnormal returns.

Even though previous studies in the literature mostly focus on other types of efficiency, few of them put emphasizes on the strong form of efficiency. Chaudhuri (1991) indicates that if the market were strongly efficient, then even an insider would not be able to profit from his privileged position. Del Brio et al. (2002) investigate the trading profits of insiders in the Spanish stock market and they find that the strong form of the EMH does not hold, since insiders earn returns that exceed risk-adjusted benchmarks. Additionally, Tahaoglu and Guner (2011) examine the return performance of insiders of companies listed on the Istanbul Stock Exchange (ISE) and their results imply that the ISE does not provide the strong form of efficiency.

Here we investigate whether the insiders' beating conditions differentiate from other investors. In this respect, we compare the inefficient insiders with the rest of the inefficient investors by looking two criteria: beating length and beating performance.

Following Maury and Pajuste (2005) and Pagano and Roell (1998), we regard the largest shareholders as equivalent to the group of insiders. We sort investors with respect to the daily average of holdings in each stock. Then we count top two shareholders as insiders for each stock. Here we consider just institutional investors since the holdings of individual investor are quite lower than the institutional investors ${ }^{6}$.

Table 16 and 17 illustrate the breakdown of inefficient institutional investors with increasing beating length and performance respectively. Both charts represent that there is no significant change of the ratio of insiders in the inefficient investors as the beating conditions rise. We examine not only the distribution of inefficient institutional investors but also the mean values of beating conditions. We try to figure out whether the beating condition values for insiders are different or not compare to non-insiders. Thusly we test the null hypothesis that the mean values of beating conditions for insiders and non-insiders are equal. Mean comparison test results for changing beating condition quintiles are represented in Table 18. The results indicate that there is only one test result which has positive $t$-value and $p$-value less than $1 \%$. The rest have negative values or $p$-values higher than $1 \%$. So we can say that the inefficient insiders cannot be differentiated from other inefficient investors. All the results above allow us to reach that we have evidences that there is a strong form of efficiency in Borsa İstanbul.

Table 16. Distribution of Insiders by Beating Length for Inefficient Institutional Investors

\begin{tabular}{|c|c|c|c|c|c|c|}
\hline \multirow{3}{*}{$\begin{array}{l}\text { Beating } \\
\text { Performance } \\
\text { Quintile }\end{array}$} & \multicolumn{3}{|c|}{ Insider } & \multicolumn{3}{|c|}{ Non-insider } \\
\hline & \multirow{2}{*}{ Proportion } & \multicolumn{2}{|c|}{ Proportion test } & \multirow{2}{*}{ Proportion } & \multicolumn{2}{|c|}{ Proportion test } \\
\hline & & $\begin{array}{c}z \text { value } \\
\text { ( } p \text { value) }\end{array}$ & $\begin{array}{l}\text { between } \\
\text { quintiles }\end{array}$ & & $\begin{array}{l}z \text { value } \\
\text { ( } p \text { value) }\end{array}$ & $\begin{array}{l}\text { between } \\
\text { quintiles }\end{array}$ \\
\hline 1 (min) & 0.11 & $\begin{array}{l}-0.60 \\
(0.55)\end{array}$ & $1-2$ & 0.89 & $\begin{array}{c}0.60 \\
(0.55)\end{array}$ & $1-2$ \\
\hline 2 & 0.15 & $\begin{array}{c}1.30 \\
(0.19)\end{array}$ & $2-3$ & 0.85 & $\begin{array}{l}-1.30 \\
(0.19)\end{array}$ & $2-3$ \\
\hline 3 & 0.09 & $\begin{array}{l}-0.08 \\
(0.93)\end{array}$ & $3-4$ & 0.91 & $\begin{array}{c}0.08 \\
(0.93) \\
\end{array}$ & $3-4$ \\
\hline 4 & 0.09 & $\begin{array}{l}-1.41 \\
(0.16)\end{array}$ & $4-5$ & 0.91 & $\begin{array}{c}1.41 \\
(0.16)\end{array}$ & $4-5$ \\
\hline $5(\max )$ & 0.17 & $\begin{array}{l}-0.88 \\
(0.38)\end{array}$ & $1-5$ & 0.83 & $\begin{array}{c}0.88 \\
(0.38)\end{array}$ & $1-5$ \\
\hline
\end{tabular}

Note: The table presents the share distribution of insiders for each run length quintile based on inefficient institutional investors. While quintile 1 contains investors with the lowest average run length, quintile 5 contains investors with the highest average run length. 
Table 17. Distribution of Insiders by Beating Performance for Inefficient Institutional Investors

\begin{tabular}{|c|c|c|c|c|c|c|}
\hline \multirow{3}{*}{$\begin{array}{c}\text { Beating } \\
\text { Performance } \\
\text { Quintile }\end{array}$} & \multicolumn{3}{|c|}{ Insider } & \multicolumn{3}{|c|}{ Non-insider } \\
\hline & \multirow{2}{*}{ Proportion } & \multicolumn{2}{|c|}{ Proportion test } & \multirow{2}{*}{ Proportion } & \multicolumn{2}{|c|}{ Proportion test } \\
\hline & & $\begin{array}{c}z \text { value } \\
\text { ( } p \text { value) }\end{array}$ & $\begin{array}{l}\text { between } \\
\text { quintiles }\end{array}$ & & $\begin{array}{c}z \text { value } \\
\text { ( } p \text { value) }\end{array}$ & $\begin{array}{l}\text { between } \\
\text { quintiles }\end{array}$ \\
\hline 1 (min) & 0.14 & $\begin{array}{c}1.15 \\
(0.25)\end{array}$ & $1-2$ & 0.86 & $\begin{array}{l}-1.15 \\
(0.25)\end{array}$ & $1-2$ \\
\hline 2 & 0.07 & $\begin{array}{c}-0.21 \\
(0.83) \\
\end{array}$ & $2-3$ & 0.93 & $\begin{array}{c}0.21 \\
(0.83) \\
\end{array}$ & $2-3$ \\
\hline 3 & 0.08 & $\begin{array}{l}-1.02 \\
(0.31)\end{array}$ & $3-4$ & 0.92 & $\begin{array}{c}1.02 \\
(0.31)\end{array}$ & $3-4$ \\
\hline 4 & 0.14 & $\begin{array}{l}-0.50 \\
(0.62) \\
\end{array}$ & $4-5$ & 0.86 & $\begin{array}{c}0.50 \\
(0.62) \\
\end{array}$ & $4-5$ \\
\hline $5(\max )$ & 0.16 & $\begin{array}{l}-0.35 \\
(0.73)\end{array}$ & $1-5$ & 0.84 & $\begin{array}{c}0.35 \\
(0.73)\end{array}$ & $1-5$ \\
\hline
\end{tabular}

Note: The table presents the share distribution of insiders for each return performance quintile based on inefficient institutional investors. While quintile 1 contains investors with the lowest average run length, quintile 5 contains investors with the highest average run length.

Table 18. Mean Comparison Test Results of Beating Conditions for Inefficient Individual Investors

\begin{tabular}{|c|c|c|c|}
\hline \multicolumn{2}{|c|}{$\begin{array}{c}\mathrm{H}_{0}: \text { Mean of Beating Length (Insiders) } \\
\text { Mean of Beating Length (Non-Insiders) }=0\end{array}$} & \multicolumn{2}{c|}{$\begin{array}{c}\mathrm{H}_{0}: \text { Mean of Beating Performance (Insiders) - } \\
\text { Mean of Beating Performance (Non-Insiders) }=0\end{array}$} \\
\hline Beating Length Quintile & t-value / p-value & $\begin{array}{c}\text { Beating Performance } \\
\text { Quintile }\end{array}$ & t-value / p-value \\
\hline 1 & $4.0437 / 0.0001$ & 1 & $-2.3346 / 0.0213$ \\
\hline 2 & $-0.1301 / 0.8967$ & 2 & $-0.4319 / 0.6672$ \\
\hline 3 & $-3.0395 / 0.0029$ & 3 & $0.7785 / 0.4385$ \\
\hline 4 & $1.0950 / 0.2758$ & 4 & $2.1275 / 0.0358$ \\
\hline 5 & $-3.9121 / 0.0001$ & 5 & $0.0678 / 0.9460$ \\
\hline
\end{tabular}

\section{Concluding Remarks}

In this paper, we aim to find who beats the market using individual and institutional trade data from a specific stock exchange, namely Borsa İstanbul. We are here mainly interested to investors who beat the market in a systematic way. Instead of market data, we use investor based data which provides us to make stronger analyses. By using investor based data, we take advantage that we can directly evaluate the performances of investors. Additionally, we deal with the details of each investor group by sub-categorizing the investor groups.

In order to find who the beaters are in a specific stock market, first we eliminate investors who are not systematic beaters. Then, we reveal the market beaters by sorting investors based on two criteria: beating length (direction) and beating performance (magnitude). To do so, we calculate the average length of runs and average value of the adjusted returns in positive runs. Thereafter we analyze the market beaters by looking to relationship with their state and descriptive characteristics. Additionally, we examine whether the insiders' beating conditions differentiate from other investors in order to understand whether the market validates the strong form efficiency or not.

Our findings allow us to reach some remarkable results. First we show that $87 \%$ of individual and $92 \%$ of institutional investors get their adjusted returns in a random way. The rest, we call them inefficient investors, are analyzed based on beating length and performance criteria. For the beating length criteria, first 
we find that the average value of investors' portfolio size and diversification increase and the turnover decreases as their average length of runs rises. And this finding is common for both of individual and institutional types of investors. Looking the descriptive analyzes; we reach that the shares of women and old individual investors, and the shares of funds and foreign institutional investors increase as the beating length investors rises. For the beating performance criteria, our results indicate that the picture becomes reversed compared to beating length criteria. This changing picture compared to beating length criteria reveals that investors in Borsa Istanbul choose between length or magnitude of beating.

All these findings present that a small minority of investors in Borsa İstanbul perform in a non-random way. When the duration of this non-randomness is first investigated, it is found that having large size and over-diversified portfolio and lower trade activity provides all type of investors to increase their chances to beat the market for a long duration. Additionally, this chance also goes up if an individual investor is female and older; and if an institutional investor is a type of fund and foreign. Secondly, when the magnitude of beating the market is employed, we reach that the conditions of being long-continued market beater is now reversed in order to beat the market by getting higher accumulated return. This important results also help us to conclude that investors in Borsa İstanbul choose between duration or magnitude of beating. Therefore, this study provides answers for the questions of not only who beats the market, but also how long and how much do they beat the market.

Furthermore, using investor based data, we investigate and test the strong form of efficiency in given exchange, Borsa İstanbul. Strong form of efficiency mainly examines whether investors can earn abnormal profits by trading on private information. In order to investigate whether any private information can cause to generate abnormal returns, the groups of investors with excess information named "insiders" are investigated due to testing for strong form of efficiency. The findings based on inefficient institutional investors indicate that the insiders cannot be differentiated from other investors. Therefore, we also come through that there is an evidence of strong form of efficiency in Borsa İstanbul.

\section{End Notes}

1. We define market beaters (beatens) as the group of investors who over-perform (under-perform) the market. That is, investors who have positive (negative) adjusted return are called as market beaters (beatens). Although the term of beater is generally used in the literature, the terms such as loser, underperformer, fool are preferred instead of beatens. In this study, the term of beaten has been intentionally chosen due to its simplicity and addition of originality.

2. We mean by "run" is the sequence of successive adjusted returns with same sign. Suppose we have following Daily adjusted returns: $0.02,0.05,-0.01,-0.02,0.01,-0.02,-0.03,-0.01,0.03$. Signs of these returns generate the sequence: ++-++-++ which contains four positive and two negative runs.

3. We define an investor as an inefficient if his/her result of runs test is not significant in $5 \%$ significance level, i.e., if $|z|>1.96$.

4. It is a fact that formal normality tests always reject on the huge sample sizes we work with today. It's even easy to prove that when $n$ gets large, even the smallest deviation from perfect normality will lead to a significant result. As $n$ gets larger, skewness and kurtosis become less important - and directed tests are likely to detect if these quantities deviate from 0 even by a small amount.

5. Since we could not find any significant change, we prefer to present the results by separating the investors in just two districts: Marmara and Other.

6. During the period of our study Individual investors that capture $21 \%$ of the market capitalization. Also, $84 \%$ of largest shareholders are institutional investors. If we consider only stocks from BiST100 Index, then this ratio increases to more than $90 \%$. 


\section{References}

Barber, B. M., \& Odean, T. (2000). Trading is hazardous to your wealth: The common stock investment performance of individual investors. The Journal of Finance, 55(2), 773-806.

Barber, B. M., \& Odean, T. (2001). Boys will be boys: Gender, overconfidence, and common stock investment. The Quarterly Journal of Economics, 116(1), 261-292.

Barber, B. M., Lee, Y. T., Liu, Y. J., \& Odean, T. (2009). Just how much do individual investors lose by trading?. The Review of Financial Studies, 22(2).

Basu, S. (1977). Investment performance of common stocks in relation to their price-earnings ratios: A test of the efficient market hypothesis. The Journal of Finance, 32(3), 663-682.

Bauer, R., Cosemans, M., \& Eichholtz, P. (2007). The performance and persistence of individual investors: Rational agents or tulip maniacs. In EFA 2007 Ljubljana Meetings Paper.

Borges, M. R. (2010). Efficient market hypothesis in European stock markets. The European Journal of Finance, 16(7), 711-726.

Brown, S. J., Goetzmann, W., Ibbotson, R. G., \& Ross, S. A. (1992). Survivorship bias in performance studies. The Review of Financial Studies, 5(4), 553-580.

Chaudhuri, S. K. (1991). Short-run Share Price Behaviour: New Evidence on Weak Form of Market Efficiency. Vikalpa, $16(4), 17-21$.

Coval, J. D., Hirshleifer, D. A., \& Shumway, T. (2005). Can individual investors beat the market?. Working paper, University of Michigan.

Dahlquist, M., Martinez, J. V., \& Söderlind, P. (2016). Individual investor activity and performance. The Review of Financial Studies, 30(3), 866-899.

Damodaran, A. (2012). Investment valuation: Tools and techniques for determining the value of any asset (Vol. 666). John Wiley \& Sons.

Del Brio, E. B., Miguel, A., \& Perote, J. (2002). An investigation of insider trading profits in the Spanish stock market. The Quarterly Review of Economics and Finance, 42(1), 73-94.

Fama, E. F. (1991). Efficient capital markets: II. The Journal of Finance, 46(5), 1575-1617.

Fama, E. F. (1995). Random walks in stock market prices. Financial Analysts Journal, 51(1), 75-80.

Ferris, S. P., Haugen, R. A., \& Makhija, A. K. (1988). Predicting contemporary volume with historic volume at differential price levels: Evidence supporting the disposition effect. The Journal of Finance, 43(3), 677-697.

Grinblatt, M., \& Keloharju, M. (2000). The investment behavior and performance of various investor types: a study of Finland's unique data set. Journal of Financial Economics, 55(1), 43-67.

Grinblatt, M., \& Keloharju, M. (2001). How distance, language, and culture influence stockholdings and trades. The Journal of Finance, 56(3), 1053-1073.

Korniotis, G. M., \& Kumar, A. (2011). Do older investors make better investment decisions?. The Review of Economics and Statistics, 93(1), 244-265.

Lehmann, B. N., \& Modest, D. M. (1987). Mutual fund performance evaluation: A comparison of benchmarks and benchmark comparisons. The Journal of Finance, 42(2), 233-265.

Malkiel, B. G., \& Fama, E. F. (1970). Efficient capital markets: A review of theory and empirical work. The Journal of Finance, 25(2), 383-417.

Maury, B., \& Pajuste, A. (2005). Multiple large shareholders and firm value. Journal of Banking \& Finance, 29(7), 18131834.

Odean, T. (1998). Are investors reluctant to realize their losses?. The Journal of Finance, 53(5), 1775-1798.

Odean, T. (1999). Do investors trade too much?. American Economic Review, 89(5), 1279-1298.

Pagano, M., \& Roell, A. (1998). The choice of stock ownership structure: agency costs, monitoring, and the decision to go public. Quarterly Journal of Economics, 187-225.

Peikun, Y. U., \& Yutao, C. W. J. L. W. (2009). Can Institutional Investors Beat Individual Investors?. Journal of Financial Research, 8, 015.

Poshakwale, S. (1996). Evidence on weak form efficiency and day of the week effect in the Indian stock market. Finance India, 10(3), 605-616.

Statman, M. (2011). Efficient markets in crisis. Journal of Investment Management, 9(2), 4-13. 
Sheskin, D.J. (2000). Handbook of parametric and nonparametric statistical procedures. Second Edition. Chapman and Hall, Florida, USA.

Tahaoglu, C., \& Guner, Z. N. (2011). An investigation of returns to insider transactions: Evidence from the Istanbul Stock Exchange. Bogazici Journal, Review of Social, Economic and Administrative Studies, 25(1), 57-77.

Thadewald, T., \& Büning, H. (2007). Jarque-Bera test and its competitors for testing normality-a power comparison. Journal of Applied Statistics, 34(1), 87-105.

Van Horne, J. C., Blume, M. E., \& Friend, I. (1975). The asset structure of individual portfolios and some implications for utility functions. The Journal of Finance, 30(2), 585-603.

Wald, A., \& Wolfowitz, J. (1940). On a test whether two samples are from the same population. The Annals of Mathematical Statistics, 11(2), 147-162.

Wermers, R. (1997). Momentum investment strategies of mutual funds, performance persistence, and survivorship bias. Unpublished Working Paper, University of Colorado. 


\section{This Page Intentionally Left Blank}

